\title{
CITIES, NATURE, JUSTICE: \\ a zoologist's perspective
}

\author{
Transforming Cultures eJournal, \\ Vol. 5 No 1 June 2010 \\ http://epress.lib.uts.edu.au/journals/TfC
}

\section{Daniel Lunney ${ }^{1}$}

\begin{abstract}
Cities and nature may seem mutually exclusive, but the animal inhabitants, both native and introduced, from pets to pests, are a major component of city life. Using Sydney as an example, this paper takes a critical look at cities and nature, more narrowly zoology, with a long-term view, i.e. one with intergenerational equity in mind. In the rapid conversion of bush to farmland, then suburbs and industrial areas, flora and fauna have not been given a strong voice. We need a new ethic for this new urban ecosystem, one which encompasses dealing with exotic species, pests and vermin on the one hand, and relic native animal populations on the other. Plans for sustainability in environment, economics and society need to recognise that these are interrelated subjects, not separate entities. I argue that knowing the natural history of Sydney is integral to understanding the city, its history, and its sustainability.
\end{abstract}

\section{Introduction}

The injustices done to nature by the growth and activities of a city can only be evaluated through a study of history. That is arguably another way of expressing the view of historian Tom Griffiths $(1991,103)$ in his engaging essay on history and natural history. He considered that historians and ecologists would agree that conservation is concerned ultimately with intimate relationships, human and non-human. He then mused that, "History - that stubbornly contextual and relativist craft - may be the tool that enables us to grope for a conservation ethic that is social as well as ecological."

As a working ecologist researching how we may conserve our native fauna, Griffiths' observations present a challenge as to what he had in mind by the word "contextual". It seems that responding to that challenge requires two things to happen. The first is for

\footnotetext{
${ }^{11}$ Department of Environment, Climate Change and Water, PO Box 1967, Hurstville NSW 2220, dan.lunney@environment.nsw.gov.au
} 
ecologists to see the merits of using the tools of the historian. That discipline, called ecological history, is growing, but only slowly. The master of this skill is Oliver Rackham, and the depth of scholarship is evident is such works as The nature of Mediterranean Europe: an ecological history (Grove and Rackham 2001) and Woodlands (Rackham 2006). There is a related strand of enquiry, now called environmental history, which is growing much more rapidly, and has many strong Australian contributors, and a website. It examines changes to the environment in political terms, movements of ideas and people, such as the European occupation of Australia, the rise of the environmental movement in the late 1960s and the class struggle of big issues, such as land ownership. For the ecologist, this is gripping reading, and helps to makes sense of the reasons for change in an historical context. It does not, however, on its own, explain the changes in the number and distribution of species in ecological terms. It does provide invaluable material and methods for looking for reasons to explain the changes, understand the present patterns, and predict future ones. To help bridge that gap, this paper looks at some of the rich historical writings that catch a zoologist's eye, especially a zoologist working as an ecologist within a city boundary. Thus the primary aim of this paper is to expand the context of historical investigations for both the historian and the ecologist, as urged by Griffiths.

With that insight, it now becomes apparent why historian Heather Goodall invited this paper by an ecologist with a research interest in urban wildlife (Lunney and Burgin 2004) and the natural history of Sydney (Lunney et al. 2010a) to present a paper on the theme of cities, nature, justice. The aim of this international symposium was to address new dialogues between the science and the social science of sustainability. History, it seems, is the tool that links Goodall's intention with a working wildlife scientist, as we all grope for an ethic of sustainability in a city environment.

When a zoologist looks at the relationship between people and animals, the matter of animal ethics appears far sooner than it did even a decade ago. It has become a popular topic in the media, usually with graphic examples, such as killing whales, or the factory farming of animals, but the level of public discussion on the subject has been limited, and often biased. It is now beginning to attract academic attention beyond the strong writings of some philosophers, such as Peter Singer (1975). While the ethical debate appears to centre on individual animals, there is the broader debate on which species are 
being privileged by our activities, whether knowingly or not, what are the consequences of the growth of cities, and the way cities are managed for nature, or more specifically, in my line of work, for wildlife. This is a central theme of this paper. However, before tackling questions that start with "should", i.e. ones with a moral question, there remains the matter of the title of the symposium to consider before venturing into the greener and quieter places of a city to look for the wildlife.

Cities, nature, justice: which word is the odd one out?

A common psychological test is to be asked to pick the most incongruous word in a sequence. Of the three words, cities, nature, justice, which word is the odd one out? Cities and justice form a common pair, with the debates over urban renewal featuring a contest over the human welfare issues involved. Cities and nature is a most unlikely pair, especially as it seems to conjure up a curious and truncated definition of nature. A case could be made that they are opposites, and present a contrast of settings both politically and environmentally. If cities is the primary word in the trilogy, then nature would seem to be the odd one out - the majority of planning ideas for cities do not mention native animals or urban wildlife, although some urge the inclusion of green spaces. Nature and justice form a pair in the context of environmental law. Justice can also be looked at from a different angle, that being the vexed matter of intergenerational equity, by asking the question of how much nature do we leave to the next generation.

Justice also calls up the idea of ethics, and injustices to nature are now beginning to be seen to demand an ethical response, not just ones of economics of land use, or engineering capability, or infastructure needs. This is the ethics of the use of the land, of the environment, and in its latest iteration, the ethics of climate change. As with the subject of the way we treat animals, this also needs public debate, particularly for urban space and urban rivers and waterways. The concept of national parks and nature reserves has endured this public exposure, with now in 2010 a far broader acceptance of the need to conserve rainforests, beaches, and river red gums, than was possible when the first NSW National Parks and Wildlife Act 1967 passed through parliament. This dichotomy between public acceptance of dedicating grand natural areas as national parks and seeing crowded city bushlands and wetlands as worthy of conservation is stark. The consequences of this dichotomy for the city animals are just as stark. The objective of a public debate is to include such city spaces into the compass of places 
worth saving and managing for their natural values. The discussion is underway, and some academic books show the depth of this discussion (e.g. Recher 1986, Adams et al. 2006, Daniels and Tait 2006, Forman 2008, McDonnell et al. 2009). This paper acknowedges the value of these ideas and takes a critical look at cities and nature, more narrowly zoology, with a long-term view, i.e. one with intergenerational equity in mind, with the first step being to look at the subtitle of the conference.

\section{Who speaks for public spaces?}

"Who speaks for public spaces?" is the question posed as the subtitle to Cities, nature, justice. The symposium aimed to address the "political, economic and ecological dilemmas of achieving social sustainability in multi-ethnic and conflictual cities in major countries of the Indian Ocean and Pacific Ocean regions". In this context, one might ask: what is a public space? The answer, as became apparent during the three-day symposium, depended on the topic selected by the presenter, and their disciplinary background. Since a public space had not been defined, then that was a reasonable approach. From this writer's perspective, it seemed that public space could be taken to imply a partial synonym for nature. One can, in one mind's eye, conjure up a map of a city with green spaces in rectangles, ovals and strips spread unevenly across a city map of roads and rivers. In that sense, green equals nature. The question of who owns, or is responsible for, these green spaces becomes an issue of land management, with a social justice dimension because of the potential to favour one or a few groups over many others in the way public space is selected then managed. In that equation, conflict can increase and social sustainability decrease, with the sustainability of any wildlife in those public spaces having no voice at all.

One aim of this paper is to define nature so that it is part of a city landscape, and to define space from the perspective of a zoologist, one with an ecological outlook. This is tackled by looking at my own city - Sydney - from the standpoint of an urban wildlife manager, as well as thinking of the history of cities to trace the way that their zoological features were seen. Another means of looking at this subject is to examine the history of land use change, or the changes and reuse of space in Sydney in the 222 years since British settlement in 1788. Nature in modern Sydney reflects the pattern in which space was consumed by development, and its zoological heritage became reduced with each phase of growth. 
There is also the issue as to whether the question, "who speaks for public spaces?" implies a moral outlook, one where there needs to be voices for those who cannot speak for themselves. For this writer, it is the wildlife that needs representation, protection by law, and an acknowledgment that space is not empty, it will be the place for some species, depending upon the different habitats present. Space also means not just one site, but a pattern of sites, and a spatially-explicit analysis of public spaces, i.e. the geography of the location of spaces, is part of the quest when seeking a long-term future for city wildlife. There is a moral message in this response to the question, that wildlife in the city does require ethical consideration, but that ethic must, in this writer's opinion, be consistent with city spaces, not an Arcadian ideal. Cities are not national parks, nor wilderness areas. That is not the ideal to impose on city wildlife managers or the public at large. Most writers about cities do have a moral quest, such as to preserve its architecture, its history, or the natural advantages of the city, while alleviating conditions for disadvantaged groups, and using space to address disadvantage. This author looks at cities ecologically, with a view to conserving their wildlife, and promoting the use of space to support city wildlife. This in turn should dovetail with the ideals of those who are aiming for sustainability, be that social, economic or political.

The title of the symposium also carries with it a sense that civilization matters. The words 'cities' and 'civilization' have the same root; justice is an integral part of being civilized, but nature and civilization have only recently become linked, and then not yet in the minds of most citizens. As a high school student from 1959-1963, I distinctly remember discussing the "man against nature" theme in the English class, whether it was Thor Heyerdahl's heroic voyage on a raft, or any of those pitched battles when nature took its toll on the stoic pioneers of the Australian outback. That was at a boys' high school, so our science was physics and chemistry; my sister at the local girls' high school could choose biology. This narrow view of nature, the future employment for boys and the battle put up by a civilized society to tame nature, reclaim the land and turn it to good account, was being enacted outside the front gate of the high school as the rural landscape of the green belt was bulldozed and built upon. My classmate Geoff Robertson went on to to become a lawyer and write such polemics as Crimes against Humanity. If our education had been more sympathetic to nature, and saw it holistically, Robertson may have written Crimes against Nature. Justice has been well served for one group of people by his pungent prose, but the very place where he grew up and played 
as a boy has been metamorphosed from green to grey. We are very late at arriving at the enlightened theme of integrating cities, nature and justice.

\section{Sydney - a global city, but with its own legacy}

Sydney is one of the major cities of the world - a global city - but its history is short by European standards. This means that the loss of nature will continue by a process that has been called an 'extinction debt', in this case, the losses of nature from the city's expansion and building programs have yet to be fully paid. Extinction of local populations of animals will continue even if no further areas become built up. This is among the messages from a forum in 2007, organised by the Royal Zoological Society of NSW, on the natural history of Sydney (Lunney et al. 2010a). As this writer's home city, Sydney evokes memories of space and its use, and loss, that play an important role in reflecting on city spaces and who speaks for them.

Two days before the cities, nature justice symposium, I was at a baseball match at Rofe Park, Berowra, on the northern edge of the city of Sydney, where the use of public space is sharply delineated. A baseball field has defined boundaries, and if you walk across them, the umpire yells at you to get off the field. There is an occupational health and safety issue involved. A baseball is a dangerous missile, and anyone within range is in potential danger. The umpire is speaking for public space, and he has much authority behind the yelling. The large patch known as Rofe Park is but one of many spread through the suburbs of the city that are devoted to sport. The habitat of the park is managed for sports games. The bush has been cleared, the ground levelled and planted with foreign grasses that are regularly mown. Some sporting fields are by the creeks and rivers, and the flat sporting fields are on reclaimed land. The very phrase "reclaimed" reveals the hegemony of the development pressures that city land has undergone. Indeed, the word "development" is itself a value judgement, one that links human progress with the transformation of natural or "undeveloped" land to productive land, at least productive from a human standpoint, and then often for just one user group. On the way home from Rofe Park to the inner west, I stopped next to the CSIRO Division of Radio Physics in Eastwood, near Macquarie University, to show my baseballer son where I lived on a farm as a boy. Radio Physics was built on that farm. 
Sydney has been the home of this author since 1946, i.e. for 30 per cent of the time of European settlement of Australia. In the immediate post-war years I lived in a number of houses in or near Eastwood. From my first memories of paddocks with horses, then through infants and primary school on dusty roads, until early high school, this was a farming district. It was part of the green belt (Winston 1957). Picking carnations, or a suite of other flowers, for the city market was a daily scene. Picking peaches on the orchard where Macquarie University now stands was regular pocket money. It was a rural lifestyle, but now it is the middle of a vast city, although bush remnants remain, particularly along the inaccessible creeks and other strips of native bush. What is so striking is the scent of that piece of bushland. It is a great surprise that, over 50 years later, that scent still exists permanently embedded in my memory. By walking along Pembroke Street, near the corner of Vimiera Rd, Eastwood, the scent of the bush remnants is evocative, and can stimulate a flood of memories that would otherwise have remained largely buried, such as the horses and carts that delivered the milk, bread and ice (for an ice chest, no fridges yet) in the late 1940s and early 1950s. The nature of smell is deeply part of our primitive memory system. While we in Australia can smell the bush, we can also imagine how the first British settlers would have responded. It must have been, and remained, foreign. That farm was part of Sydney's green belt.

If you are a Sydneysider, you can elicit many memories from fellow locals. One colleague, Chris Moon, on reading this text, remembered his great grandmother who grew up in the 1870 s on a dairy farm in Goulburn St, Surry Hills. Each day she carried the milk over the paddocks as far as the University of Sydney. Chris Moon said that she is remembered by his still living father - i.e. there still exists a tangible link to that phase of Sydney's development. Total transformation has been rapid - within people's lifetimes. How long, Chris Moon wondered, before Eastwood looks like Surry Hills?

On the questions of open space, green belts and planning, Denis Winston (1957) wrote what appears to be an angry, but optimistic, book, Sydney's great experiment. The progress of the Cumberland County Plan. The feisty style of this professor of town and country planning is evident in the first paragraph of his foreword: "I have long thought, and said, that the Cumberland County Council were at fault in not making available to the general public a simple account of their work to explain the purpose of the Planning Scheme and tell what has been achieved so far. Now the Chairman, Councillor Luke, 
has asked me to write this account, though I have warned him that I shall say exactly what I think." Winston then becomes thoughtful and even issues an appeal to his readers: "Most people of goodwill support the idea of having a plan to control the development of this vital area of the County of Cumberland which contains nearly a quarter of the population of Australia..." The Cumberland Plain extending from Port Jackson to Penrith, from the Hawkesbury River to Appin in the south, is a useful description of Sydney as a city. Winston made this appeal because, in his own words: "Nearly everyone is aware of the real mess we have made of our cities and their surroundings during the last hundred years; and we have now got to the stage where we can hardly bear to live in them and, as for efficiency, if ever we are really in a hurry we have to get out of our car and walk." That was written 53 years ago, and it has a familiar ring. However, the curtain was about to come down on the plan, and especially the green belt.

Harrison $(1978,143)$, an urban researcher, wrote that the Cumberland Plan was the most definitive expression of public policy on the form and content of an Australian metropolitan area ever adopted. He noted that some of its more important features were without precedent; it prescribed the outer limits of urban growth by an encircling green belt zone, reserved land for open space and future highways, and zoned areas for industrial expansion in the middle of outer suburbs. Harrison then noted that the somewhat precipitate abolition of most of the restraining green belt by the Minister for Local Government, without consultation with the Cumberland County Council, occurred in December 1959. For this author, the change was particularly noticeable. Rapid urban development occupied the period after 1959, my first year of High School at Epping Boys High, on the corner of Epping Highway and Vimiera Rd, and a short walk from where Macquarie University now stands. I now recognise that I witnessed the rapid transformation of native bush and a rural landscape into crowded housing estates and busy roads. A grand vision of a green belt, a brilliant green landscape, had been sold into mediocrity, to a suburban model that had nothing special to offer to a zoologist. I wonder whether I would have become a zoologist if I had not been imprinted with open spaces and lots of animals, both native and introduced.

The inner west, where I now live, is crowded by comparison with the green belt of my childhood, and it underwent this suburban development rush from farms in the last part 
of the $19^{\text {th }}$ century, but it has more cultural diversity and that is much of its attraction. I was able to walk to the venue of the cities, nature, justice symposium, so I see city life at its hub. I am thus committed to Sydney as a city, but I can see as I walk the lizards, the birds and, at night, the nationally-threatened Grey-headed Flying-foxes Pteropus poliocephalus, as well as the introduced Black Rats Rattus rattus darting along fence lines near the garbage bins. I would encourage far more diversity of wildlife as the inner west is refurbished and gardening takes on a new direction in an era of climate change, but it does seem that it will take much talking, writing and action to bring about a more sustainable inner city environment for wildlife. Wildlife is largely a foreign concept in the inner west, and re-learning nature does seem to be a slow process.

\section{Early descriptions of the nature of Sydney with an emphasis on fauna} Food and fauna

Historian Grace Karskens (2009) has taken a lively interest in Sydney as a colony, and for a zoologist there is much of interest in her work. One intriguing example is the rat which Karskens $(2009,270)$ said had been described as "our enemy, the rats". She cited Tim Flannery, who believed they were the White-footed Rabbit-rat Conilurus albipes and that it had disappeared by the end of 1791. In reading Flannery $(2003,20-21)$, it is part of his broader view of the general pattern of decline that may have followed the end of native fire. Flannery here is site specific. He stated that when the first fleeters established the settlement at Parramatta, they found that their stores were being raided by a large, handsome native rat. He also commented that it is strange that, just about everywhere that there are records of it, the first European record is also its last. So, said Flannery, the drawing made of it by an anonymous first fleet artist around 1791 is both its first and last record from Sydney. This is certainly a curious story. However, it is consistent with that found by Lunney (2001) in looking at the cascade of extinction in western NSW in the $19^{\text {th }}$ century. The diary of one of the first explorers recorded what is best interpreted as this species, but it was never seen again. Until the diary, recently published, was read with zoological eyes and published in Lunney (2001), it had never been listed as a species of western NSW. This raises the question of how many other species have been lost before recording (and here we are talking of a large, conspicuous mammal). Quolls, both the Spotted-tailed Quoll Dasyurus maculatus and the Eastern Quoll D. viverrinus were conspicuous by their spots and, as Karskens (p 270) reported 
from the settlers' records, they were "very destructive of our eggs and poultry". They too have gone from Sydney, and D. viverrinus from the mainland altogether; it now only inhabits Tasmania, and D. maculatus is a nationally threatened species. Karskens ( $p$ 271) is well aware of the changes, and observed that the face of the country around Sydney was in constant flux. She commented that although many of Sydney's suburbs and parklands are alive with birds, many of those painted so beautifully by the early artists are no longer found in the Sydney region. Karskens listed, among others, Brolgas, Magpie Geese and Blue-faced Honeyeaters. What is noticeable here is the beauty of these animals, so it was attractive to paint them, and their records become clear. The Brolgas and Magpie geese are also large animals, and are wetland animals, so on both counts are likely to be more vulnerable to change. It is only by using a range of sources, such as paintings, that scholars can establish species, places and dates. Karskens (2009) has identified the subject, but it remains to be seen whether it goes much beyond the colourful, the pest and the food sources.

The local wildlife was food, and valuable food at that. Karskens (p 274) cited that "Our kangaroo rats are like mutton, but much leaner", and commented that the local fish were common in summer but in winter they were scarce, oysters were devoured with gusto, the officers dined on kangaroo and emu, and on exploratory trips, ducks, crows, cockatoos and anything else they could shoot went into the cooking pots or roasting spits. By the early 1800s, Karskens (p 274) noted, the early accounts considered that Sydney was wonderfully healthy, where a fine climate and abundant fresh fruit and vegetables could bring even half-dead scurvy victims back to life. Karskens found it strange that the constant early references to native foods have been largely ignored or dismissed in historical accounts. I agree, it is strange, but I add that it remains strange. Lunney (2010) examined the history of the debate over the commercial harvesting of kangaroos 1948-2009. It is both a strongly supported and bitterly opposed industry, yet the current program in NSW is, for the first time, based on a commercial harvest rather than a pest mitigation paradigm. As was noted over 200 years ago that kangaroos have lean meat, and this is one of the claims for their health benefits. Archer and Beale (2004) have taken up the cause of "going native", i.e. advocating turning to native foods and moving away from the imported material on the basis that Australian ecosystems support native species far better than imported plants and animals. Historians, usually regarded as normal citizens, are simply caught up in the normal world of eating 
European foods. Karskens may be leading her colleagues away from that blind spot, and food studies will materially help the wider cause of determining the early natural history of Sydney, and its subsequent urban transformation.

The detailed study by Attenbrow (2010) gives a comprehensive description of the foods the Aboriginal people ate from her studies of the archaeological and historical records of Sydney's Aboriginal past. Such careful scholarship demonstrates what can be found, and points to where the records lie. Marine resources were an important part of people living along the coast and estuaries. These included fish, molluscs, crustacean and marine mammals, with fish most often noted as the main food source. Attenbrow reports that, in summary, kangaroos, wallabies, possums, gliders, flying-foxes and kangaroo rats were reported to be eaten, with possums being a major food source in the hinterland. Dingoes, koalas and wombats were noted as food only among the hinterland groups. Attenbrow also gives locations, and sources, so for those wishing to employ this information for other purposes, there is a great resource in her work. The application here is that Sydney was sufficiently bountiful to be able to sustain a population of Aboriginal people prior to European settlement, and that the distribution of that population would have reflected the availability of food. Availability is not the same as numbers of animals, some are present but so hard to catch that they are operationally not available. There is no suggestion that the current distribution of people reflects the capacity of the land to provide food, which means that the current human population is disconnected from that vital attribute of survival. That is a phenomenon of cities, and Sydney is no different in that respect. What is so engaging here is that records are so recent, a bare 222 years since the first fleet, and it is possible to get a glimpse of the fauna of Sydney from the day that it began to become a modern city, one where wildlife was not regarded as either important or needing management, and was largely unnoticed at the level of planning and city development. This paper endeavours to encourage readers to re-imagine Sydney's wildlife at 1788, and use that both as starting point for ecological reconstruction, and for engaging the interest of today's citizens in the enterprise of being a more sustainable city, with wildlife being a yardstick of any successes.

\section{A changing complement of animals}

Karskens $(2009,269)$ noted that by the 1820s Dingoes Canis lupus were thought to have become taller through breeding with domestic dogs, and by the 1830 s they were a 
nuisance in Sydney streets. Thus in less than 30 years, Sydney had been set on a trajectory to a new natural history. Governor Phillip, reported Karskens (p 269), "kept kangaroos at Government House and in quieter moments would enjoy feeding a bat, which would 'hang by one leg all day". This is an ecologically intriguing statement. Phillip was governor from 1788-92, so "kept" probably meant that he fed the kangaroos, or they were in his yard regularly, but the idea that he had a fenced population does not seem feasible. They have never been farmed, but shot wild. It does say that kangaroos were in the heart of Sydney, and that raises the question of whether they were Grey Kangaroos Macropus giganteus, i.e. large animals, or whether they were smaller and more secretive wallabies. We need a bit more information. The bat presumably was a flying-fox, almost certainly the Grey-headed Flying-fox, the very species that is such a vexatious animal in the Royal Botanical Gardens today. Is it also saying that this bat was likely to have been found nearby, such as the present day site of the Gardens? If so, it is an intriguing first record.

Birch and Macmillan (1962) looked at the Sydney scene, as they called it. They reported on the bubonic plague that invaded Sydney in March 1900. In all, they reported, 112 people in Sydney died from the plague. The government quarantined the rat-infested wharves of Darling Harbour and Millers Point. (I am not certain of the rat, it was certainly an invading species, not native, and was most likely the Black Rat Rattus rattus, but undoubtedly the Norwegian Rat $R$. norvegicus was also present.) The waterfront was brought to a standstill while whitewashing, fumigation and rat-catching went on feverishly, Birch and Macmillan recounted. The subject persists, and exotic rats remain an issue - just check the rat traps and rat bait on the shelves of your local supermarket.

\section{From the city in history to the ecology of cities and towns}

Mumford (1961), in his major work The city in history, made the point that if we would lay a new foundation for urban life, we must understand the historic nature of the city, and distinguish between its original functions, those that have emerged from it, and those that may yet be called forth. Sydney offers such an opportunity, with a known starting date of 26 January 1788, but I also add that we need to look at history to help explain natural history, its origins and how its meaning has changed, and for that we 
need to see cities as being alive to more than people. Sjoberg (1965) noted that the first cities arose about 5,500 years ago, but that large-scale urbanisation began only about the middle of the $19^{\text {th }}$ century. His paper is one of a series of reprints of thoughtful papers published in Scientific American on Cities: their origin, growth and human impact. Davis (1973), in his preface to this collection, commented that one might think that, since research on cities is not a conventional field of science, Scientific American should not devote space to it. No one can doubt, said Davis, that cities are actual phenomena and therefore susceptible to scientific investigation. Davis noted that in fact they have been the subject of recent intense investigation in numerous disciplines. In looking through the reprints, I did not find wildlife, natural history or animals covered. These add to the numerous disciplines encompassed by cities. I noted from Davis' figure 1 (1850-1970), in the introductory section to the evolution of western industrial cities, that Australia had the highest percentage of its total population living in cities of 100,000-plus people. This raises an important point that we rarely see covered, namely the question of how city dwellers learn about animals, about wildlife and the natural history of where they live. This question gains importance as the population of a country becomes increasingly urbanised. From this graph, Australia should be a leader in this matter, but that is not my reading of the situation. There are many great insights, in various publications, but they have yet to penetrate far into the planning system, or to other cultural worlds, such as economics.

\section{Urban wildlife}

\section{Backyards and urban fringes}

In their and friendly but learned book Backyards, Lesley Head and Pat Muir (2007, p 154) recognise that urban Australia values its relationships with plants, pets, birds, other animals, the earth and the weather. Connections, they point out, are developed through daily habit and close observation, and involve all the senses. They concluded that the passion engendered in suburban backyards, and the everyday, habitual nature of these engagements, provide an under-rated human resource of considerable potential in the necessary shifts towards more sustainable cities. Their example is Wollongong, a city just south of Sydney, and therefore relevant to a Sydney view of the world. My addition to that view is that it does take some specialised skill to know both the details of all the fauna, and the history of what was present. Today's backyards have a faunal history, 
and finding out that history can be as exciting as the TV series Who do you think you are? but with the focus on species diversity, not a diverse human family tree. Try to reimagine your backyard in 1788, and think of the wildlife that lived on that spot. It is a constructive precursor to looking at how and where backyards are planned for a city.

In their book Urban wildlife: more than meets the eye, Lunney and Burgin (2004) canvassed subjects that are now becoming more readily accepted as interesting, namely that urban wildlife is a topic in itself. This applies to backyards and city parks, and also to the city fringes and other areas that have retained native bush habitats and fauna. The Koalas in Campbelltown are a case in point. In their history of the Koalas in the southwest of Sydney in and around Campbelltown, Lunney et al. (2010b) put a planning framework over the area by making their study map-based, because it is via maps that we can plan to conserve. The historians' approach is often confined to general or descriptive maps, but conservation depends upon cadastral maps, i.e. maps of land tenure. In my experience, if you do not have a map that can be used by planners, you do not have a basic unit of conservation in our tenure-bound society. This highlights the importance of planning, and thereby the role of local government in seeing and appreciating habitats, and conserving them within their Local Environment Plan (known in the trade as LEPs). In reflecting on why cities change, Faulkner (1982) used Campbelltown as a case study of planned urban expansion. In the years following World War II, the area was made up of villages providing dairy products, poultry and fruit to the Sydney markets. It then became part of development schemes, and Faulkner commented on some of the limitations of the Macarthur Development Board, particularly its inability or unwillingness to analyse social trends in a rapidly growing population. Faulkner $(1982,282)$ noted that the Board's professional staff were mainly engineers and architects, and then lamented that the bricks and mortar mentality will probably become more firmly entrenched as financial support from government declines and the Board becomes more dependent upon revenue from its development activities. Lunney et al. (2010b) noted that by 1986 there was agitation to prevent development impinging on the Campbelltown Koalas. That story is still unfolding, but the general lesson that we draw is that Sydney is more than bricks and mortar. It includes its native flora and fauna, and they need specialist skills in parallel with engineers and architects and sociologists. 
The scientist in city life

The issue of the role of scientists in city life had simultaneously been seen by historian Libby Robin (2007). Robin $(2007,9)$ posed a searching question by asking how much has our identity been formed by Australia's environmental opportunities and constraints? Robin noted that while history, political science and other humanities speak about the nation-state, science provides the voice of the natural world. Scientists, said Robin, are the most prominent speakers, not just for the cute and cuddlies, but also for rivers, land management, air quality and marine microbiology. Robin and Harry Recher (see discussion below) are right in my opinion, but these are not the disciplines which have had the most influence on the shape, culture and development of Sydney. I argue for a better integration of the different approaches to Sydney as a city with such a rich natural history setting, one eminently worth studying, conserving and promoting if ever we are to integrate the themes of cities, nature and justice.

\section{A new ethic for a new ecosystem}

Ecologist Harry Recher opened a number of themes in the plenary session on a forum on the natural history of Sydney (recorded in Lunney et al. 2010a), each of which could run to another book, centred on the concept of natural, the management of existing natural areas, the importance of peri-urban Sydney, and a challenge as to what we really want for the fauna of Sydney. These are aesthetic, ethical and managerial questions, but underlying them is the need to grasp the ecological side of what we can see and manage. Recher is an experienced ecologist, and he also knows how to get a controversial idea into a coherent thesis. He elaborated on some of the ideas in his own paper in The natural history of Sydney. Recher (2010) points out that, to a considerable extent, the region owes the biological richness of its native vertebrates to large expanses of native vegetation on the urban perimeter, with many fewer species maintaining breeding populations in the urban, suburban and rural terrestrial habitats as true commensals of human society. The greatest vertebrate biological diversity in the region's more developed areas is the vast array of exotic fish, reptiles, birds and mammals, including Australian species exotic to the region, kept by people as companion animals, pets and working animals (e.g., racehorses, livestock, those in zoos and animal parks, laboratory rats) and their feral counterparts. These animals constitute by far the greatest diversity, if not abundance, of terrestrial vertebrates in the Sydney Region and interact significantly with the city's culture, ecology and economy. Recher argues that 
recognition of the importance of non-native animals (and plants) to urban society and ecosystems is overdue. We may be unwilling, says Recher, to accept companion animals and exotic species as 'wildlife', but we cannot deny their existence as part of the urban fauna nor their importance to urban lifestyles. Equally, Recher points out, the urban landscape can be important for the conservation of continental biodiversity by providing additional habitat for native animals and plants and by bringing city dwellers into contact with native species which they might not otherwise encounter or even be aware of. Thus, Recher concludes, the conservation and management of an urban fauna is fundamentally different from that required outside the urban environment. This is strong ecological writing, and it does call for a new look at the ethical basis of how we manage our urban fauna.

In the process of considering the animals with which we share our city, there is the issue of how we should treat animals, and this is an ethical question. This then raises the question of whether we need a new ethic for this new ecosystem. That new ethic would encompass dealing with exotic species, pests and vermin on the one hand, and family pets or relic populations of native animals, such as Common Brushtail Possums Trichosurus vulpecula, on the other, translocating or even killing some, but being kind to others. This is different to the balance of attitudes to animals in a rural landscape, or a wilderness area. The list of species will overlap, but not the problems and priorities. This means we need a new code of practice for city fauna. To make that comprehensive, we need to grasp the natural history of the area, and recognise, in development plans, what species we are favouring and what species we are hostile to. This recognition of a new ethic needs a review of our current ethical basis for managing wildlife.

Brian Gilligan was the last Director-General of the NSW National Parks and Wildlife Service, before it became part of a larger, merged department in 2003. He recently wrote a paper reflecting on wildlife management during his time. Gilligan (2009) commented on the complexities of community perceptions and responses to wildlife management issues, for example, he noted that half the people in Sydney's leafy suburbs feed Brushtail Possums while the other half curse them for rampaging nightly on the roof. This allows another observation to be made, namely that many of the wildlife management decisions are site specific, both within a city, and considering the city as a whole in contrast to the rest of the country. 
Cities are recent in human evolution, arguably demanding a new code of practice for managing wildlife because this is a new ecosystem. We need a different level of tolerance of wildlife, as well as a tolerance of those who do not like wildlife, and the way we enforce the wildlife laws. The two largest categories in the (vertebrate) animal world are those that we regard as pests, and those that are not. In cities, it is usually the introduced species we attempt to control, such as by poisoning, to suppress populations. That might sound unattractive, until you know that the population under consideration is of black rats at the back of your local restaurant. Rats are only one step more popular than cockroaches, yet while invertebrates gain a poor mention in most discussions of city wildlife, they constitute most of the species and most of the numbers of individuals. An observation from these discussions is that there is no single word that defines our relationship to city animals - it can be caring, minding, looking, controlling, exterminating, tolerating, ignoring, liberating, protecting or managing. The very fact that a range of words encompasses our relationships to animals identifies the scale of the test facing those who attempt to manage city wildlife.

"When it comes to relations with the animal realm, the Australian nation and its people have a troubled history and a deeply troubled present. Yet, and perhaps because of this, Australia has produced several key thinkers in the field of human/animal relations. Peter Singer's Animal Liberation was as important to animal rights as Germaine Greer's The Female Eunuch was to feminism..." With these words, literary editor David Brooks (2009) looked at animals as a relationship that has a deep moral meaning. It raises the question: how would he manage the urban wildlife of Sydney? He would likely turn to Peter Singer (1975). In my opinion, Singer's zoological reach is confined to animals that most people know - mostly those large vertebrates which are 'sentient' and have been subject to much cruelty (Lunney ms a,b). Factory farming is the current bete noir of the animal liberation movement. This potentially leaves us indifferent to species of animals that are not in the public eye, or which fall below Singer's definition of sentience. It is these groups that the animal liberation philosophy does not effectively reach, because its concerns are about our treatment of individual animals, rights and justice, not ecology. As a consequence, the animal liberation approach is limited in its application to managing urban wildlife. However, it does provide an ethical position which can be part of any discussion for our cohabitation with city animals, although the concept of welfare is more relevant and applicable than liberation. 
We need our planning system to expand to encompass city wildlife. The development of a code of practice for urban wildlife would need to address issues under such headings as fauna populations, animal welfare, identifying and mapping wildlife habitat, incorporating mapped habitat into formal plans, monitoring the outcomes, and adjusting boundaries and site management plans accordingly, and also include education for all interested parties. There is already a range of legislation and local, State and Commonwealth action, and planning provisions that cover these matters to a greater or lesser extent, depending on the subject, but they are largely unconnected ecologically. Integrating all of them is a major challenge. Those links can be hard to see, and hard to manage, given the background of current decision-making processes, and the lack of local expertise. However, it is principally the lack of recognition that the zoology of a city is fascinating, is part of its heritage, and can provide a clear measure of managing the space, and the flows, of city life sustainably - that is the message of this paper.

To put more substance to the idea of a code of practice to conserve city wildlife, it is instructive to look just at animals as an example. Wildlife management, and city wildlife is no exception, now falls into three categories: threatened species, pest species, and those that fit in between. The last group has by far the largest number of members, but they do not impinge on us to nearly the same extent as the other two, which consequently command both the limelight and the funds. The issue of overabundant animals, i.e. pests, is often the most vexatious, because of polarised views on the options for management. Nevertheless, a code can be devised to deal with these animals, and what follows draws on Lunney et al. (2007a). The headings for such a code are: humane treatment of individual animals; the responsibility for damages caused by native species; population targets; what ethical principles should be adopted, and which species to favour. The perceived need to act when confronted with problem species, independently of the inaction, or even hostility, of others, is an ethical issue. The ethical choice arises from the need to distinguish between the position taken by animal rights groups, which argue that no harm, culling, or even any interference should occur, and the animal welfare approach, which is the one that exists under NSW legislation in the Prevention of Cruelty to Animals Act 1979. It is the widely accepted approach. The Animal Ethics Committees for animal research have a workable model, but its limitations need to be understood as well (Lunney ms c), including fear of criticism that can curb new ideas and lead to becoming too risk averse. Inaction may 
appease the animal rights lobby, and keep difficult decisions out of the media, but the responsibility to act remains. This is particularly the case with urban wildlife, where people need a firm response. This raises the matter of what principles of procedural justice should be followed to assure fair representation in decision-making? I argue that zoologists, those with an ecological outlook, need to be included. Decision-making does not belong, in my view, to any one group, such as lawyers or philosophers, and it really ought to encompass historians, those who can see the Aboriginal past, as well as city planners and those who are keen to see a sustainable city ecosystem take shape. By not facing these issues, we shall continue to leave the future of city wildlife to chance, or more likely, we shall deal only with a few demanding species and ignore the rest. On the basis of what we have seen in the last 222 years in Sydney, that does not leave us with a good prognosis for an extended period of co-existing ecologically with our rich faunal heritage. Imagine what that heritage will be in another 222 years. If that looks as drab to you as it does to me, then that might be a spur to look at what we have now, think ecologically, and draw disparate ideas together, of which cities, nature and justice presents one of the newest and most provocative combinations.

\section{Ends and means in urban planning}

Patrick Troy $(2000,1)$ made a fundamentally important observation in his chapter entitled Ends and means in the book he edited, Equity, environment, efficiency: ethics and economics in urban Australia, when he identified that the subject of urban policy has an ethical dimension. He pointed out that one of the major problems we now encounter in exploring urban policy is the difficulty in making transparent the ethical conditions or assumptions on which economic analysis is based. Who gains and who loses, Troy stated, along with when and how activities take place, and the space they use and their location, all raise ethical issues. To Troy's concerns, I add the issue of urban wildlife, the natural history of a city, and specifically the support for studying the natural history of Sydney, recording it and applying the findings to better manage the local native habitats from backyards to national parks. With such a rich faunal heritage, and widespread interest in nature, there arises an ethical dimension of what should be studied, conserved or allowed to be lost to development, i.e. the broad ethical questions that underlie the view that we should sustain or largely ignore that heritage. To let it count for nought in any planning decision based primarily on economic criteria is itself 
an ethical choice, one often made, I consider, without acknowledgement that the decisions being made have an ethical dimension.

Troy $(2000,4)$ also put a new interpretation on the County of Cumberland Planning Scheme of 1948 (see Winston 1957). He saw it in the historical context of the need for reform of cities in the post-war years. Troy saw these early town planning schemes as placing great emphasis on ensuring the provision of public open space for active and passive community recreation and for green space to improve the quality of the environment, especially air quality. The green belt revealed just such concern, Troy remarked. Green space, in my zoological view, serves native fauna well, but there is a case for its skilled selection and management and for sustaining its integrity. These offer chances to find fauna not previously known locally and for subsequent generations to treasure such a legacy.

Frank Stilwell $(2000,15)$ added to Troy's thesis by depicting three interlocking systems - economic, social and ecological - whose interaction shapes the degree of equity, the possibility of ecological sustainability and the quality of life. Specifically, Stilwell $(2000,32)$ saw the greatest challenge being in the reformulation of urban political economy to be recast in the context of ecological economics. He added (p 33) that it would be a huge research agenda to determine what would constitute the necessary sectoral-spatial restructuring to meet the goal of ecological sustainability. Other than seeing the vastness of the problem, there was little clue how one might go about the research, except for Stilwell's reference to the works of Herman Daly and other ecological economists. I have a suggestion: start with knowing the natural history of the area, and for Sydney, there are rich and immediate offerings. Heather Goodall's (2010) paper in the book The natural history of Sydney is one of the ways of seeing, which is the title of Stilwell's chapter.

Ecological sustainability that does not take the fauna into account is not sustainability at all, in my opinion. Words such as fauna, wildlife, native animals, zoologists, botanists, museums, national parks and nature reserves, habitat, threatened species, invasive species, climate change and fire management are all part of ecological sustainability. It is a subject area that is largely missing from the urban planning books I have read, especially those that were written before 2000, and when ecology and sustainability 
were linked, one gains little sense that natural history was part of that thought process. Nevertheless, we all gain enormously from these works in terms of the care for others, for good governance of our cities from a planning perspective, and the need for amenity for the people of cities. To that cause, I argue, we need to include natural history and urban wildlife as part of the compass of amenity, and ecological sustainability.

\section{Sydney as a sustainable city}

State of Australian Cities Conference 2005

In her rapporteur's summary of the environmental city, Grace Karskens (2006, 9), as an historian, provided many insights that resonate for zoologists. Under the heading "rethinking sustainability - words and priorities for urban country", Karskens noted that language shapes ideas and practice, that language is a battleground, it can be a cloak for the very interests who are causing environmental problems, and it can be deployed to postpone any real action. She suggested that the problem lies not in calling for sustainability in environment, economics and society, but in the way this is seen (Karskens' italics) - as though these are separate arenas, she added, and as though achieving sustainability in one is as good as achieving it in another. This, she saw, is emerging as the comfortable, business-as-usual, greenwash approach. To that, Karskens added, the way they should be seen is for what they are: interrelated aspects of the whole. To achieve environmental sustainability, it is necessary, Karskens concluded, to look at economics and social impacts, and vice versa. I agree, and to that I add seeing the natural history of Sydney as integral to understanding the city, its history, and its sustainability.

Greenwash is not in the Macquarie Dictionary, $3^{\text {rd }}$ edition, but can be understood from the reference to whitewash, which is defined as "anything used to cover up defects, gloss over faults or errors, or give a specious semblance of respectability, honesty etc." Greenwash is all too easy to perpetrate, in my opinion, in relation to natural history if it is not understood and valued. Green areas do not automatically equate to understanding and managing the diversity of the fauna in Sydney. The fish in Sydney Harbour, for example, do not seek green space, as it is so often referred to, and restoration plans do need to know the local flora and fauna existing in a place before cleaning up the bush, weeding and planting. Zoologists have much to contribute to this discussion, yet it has 
been the humanities disciplines, such as history, that have been the first to see this link between fauna, planning and economic development, at least in my reading of the wide range of material available. However, I note that Karskens used the term green space in conjunction with the awkward word "ecologies" and people. I think that the word here should be environment - ecology is "the study of the ways that organisms interact with each other and their abiotic environment". That definition comes from the textbook Ecology in Australia: a natural legacy (Recher et al. 1986), a book that was written to be free of jargon for all those who use, or would benefit from using, ecological ideas. Some of the ideas are now common, but there is a way to go yet if the conference at which Karskens spoke - the State of Australian Cities 2005 - is any guide.

Karskens (2006, p 10) did note the importance of greenspace for countering heat, for urban biodiversity, for urban well-being, and for sheer aesthetic value, as well as providing services for cities - purifying water and air, for example. Karskens added that greenspaces are also complex human places, tied in with and interpreted through all kinds of ideas about nature and how we relate to it. She then made the telling observation that we should be able to tap into latent and semiconscious enjoyment of urban life to translate concern over wilderness into concern over cities and all the species that live there. With regard to biodiversity in greenspaces, our cities, noted Karskens, are in fact are not only human habitats, they are now refuges and habitats for many wild animals and rare plants - they are their homes too. Karskens then framed a key question: But how do people relate to this? The cities, nature, justice symposium is a powerful way to respond that question.

\section{Sydney as a global city}

Bryan et al. (2006) looked at Sydney as a global city in the same conference as Karskens (2006). It is fascinating to see Sydney through the eyes of experts in economics, government and international relations. It is rather distant at first glance from the way zoologists see a city, but it converges on the issue of sustainable urban outcomes. Bryan et al. noted that there is an ascendant academic argument that key economic processes are increasingly built at the scale of the city and, in turn, that successful urban economies are increasingly detached from their traditional hinterlands. Cities, in this city-centric global economy, are argued to be immersed in and driven by globalised networks and connections. Drawing on the example of Sydney, Bryan et al. 
argued for the need to develop more grounded theoretical understandings of what drives contemporary accumulation and distribution processes in a global city. They sketched what might be learned from tracing the reach of Sydney's economy through changing patterns of materials, information and financial flows to produce a spatial political economy of the city. They then argue that this grounded understanding will leave us better positioned to devise management strategies aimed at producing more efficient, equitable and sustainable urban outcomes. What zoologists see is a similarity of language of economics and ecology, there is after all a common Greek root to the words, but recognise that the economists are speaking about goods and services that are traded, not set aside as national parks, or studied and conserved as natural history treasures. Is there a gap in understanding here? In their paper I found an engaging detail, and therefore a point of contact - the fact that Sydney was their case study.

\section{Conclusion}

Among the many conclusions that could be drawn from this subject, the one that leaps from the reading of the ideas of the many writers about cities, and Sydney in particular, is that an inattention to urban wildlife constrains our capacity to resolve the dilemmas of how to live ecologically as city dwellers. A new cultural dialogue is emerging to grapple with the political, economic and ecological dilemmas of achieving social sustainability in cities. We need a better grasp of both the biology of urban wildlife, or urban nature, and the recent emergence of its ethical and aesthetic dimensions. There is an unacknowledged history of city wildlife, rife with conflict from the Roman gladiators killing lions to our contemporary hostility to flying-fox camps in the city. City dwellers also love their exotic pets, kill rats, loathe cockroaches and fear snakes. If we are to do justice to the nature of our cities, we could start with taking an ecological view of the city as an ecosystem, construct an ethic that is city-based, not wilderness-focussed, and enjoy and encourage the diversity of the animals that readily cohabit within our cities. This will require a political shift in thinking about sustainability, an ethical debate on who owns the animals and how to treat them, and a recognition of cities as living places. This debate can be enriched by a sense of the history of towns and cities, especially as they predominantly occur on the fertile lands, along rivers and around estuarine ecosystems - all originally providing prime habitats for fauna. We need to acquire new skills in looking at wildlife, to complement the inspired architects and 
artists, planners and social historians, by seeing the animal populations living in the green spaces with a new eye for animal habitats, their movement patterns and food sources. This would give one strand of cohesion to the creative juxtaposition of our expanding ideas about cities, nature and justice.

\section{Acknowledgements}

I am indebted to Heather Goodall for the invitation to speak at the symposium, and to the skilled specialists across a wide spectrum of cultural backgrounds. I also wish to thank Chris Moon and two anonymous referees for their critical reading of the ms.

\section{References}

Adams, C.E., K.J.Lindsey and S.J.Ash (2006) Urban wildlife management, Boca Raton, Florida, USA: CRC group, Taylor and Francis group.

Attenbrow, V. (2010) (Second edition) Sydney's Aboriginal past: investigating the archaeological and historical records. University of NSW, Sydney 2052, Australia.

Archer, M. and B.Beale (2004) Going Native, Australia: Hodder Headline.

Birch, A. and D.S.Macmillan (1962) "The Sydney scene", reprinted (1978) in The Australian city Unit A, Marvellous Melbourne. A study of nineteenth century urban growth, Victoria: Deakin University, School of Humanities, Open Campus Program: 271-272.

Brooks, D. (2009) Editorial. Southerly 69: 5-17. (This edition of the journal had the title Animal.)

Bryan, D., P.McGuirk, P.O’Neill and F.Stilwell (2006) "Understanding Sydney as a Global City", in P.Troy (ed.) The State of Australian Cities, State of Australian Cities http://www.griffith.edu.au/_data/assets/pdf_file/0005/81239/city-economy-12bryan.pdf, last accessed 5 March 2010: 1-11.

Daniels, C.B. and C.J.Tait (eds) (2006) Adelaide, nature of a city: the ecology of a dynamic city from 1836 to 2036, Adelaide: Biocity, centre for urban habitats.

Davis, K. (1973) preface in Cities: their origin, growth and human impact. Scientific American readings, San Francisco, California, USA: W.H.Freeman and Co.

Faulkner, H.W. (1982) "Campbelltown. A case study of planned urban expansion”, in Why cities change. Urban development and economic change in Sydney, North Sydney: George Allen and Unwin: 265-282.

Flannery, T. (2003) "Beautiful Lies. Population and environment in Australia",. Quarterly Essay 9: 1-73.

Forman, R. T. T. (2008) Urban regions: ecology and planning beyond the city. Cambridge University Press, Cambridge, UK. 
Gilligan, B. (2009). Reflections on national parks and fauna conservation in NSW. Australian Zoologist 35: 1-8.

Goodall, H. (2010) "Nets, Backyards And The Bush: the Clashing Cultures Of Nature On The Georges River", in D.Lunney, P.Hutchings and D.Hochuli (eds) The natural history of Sydney, Mosman, NSW: Royal Zoological Society of NSW.

Griffiths, T.R. (1991) "History and natural history. Conservation movements in conflict", in D.J.Mulvaney (ed.) The Humanities and the Australian environment, Canberra: Australian Academy of the Humanities: 87-109.

Grove, A. T. and O.Rackham (2001) The nature of Mediterranean Europe: an ecological history, New Haven, Connecticut: Yale University Press.

Harrison, P. (1978) "City planning”, in P.Scott (ed.) Australian cities and public policy, Melbourne: Georgian House: 141-173.

Head, L. and P.Muir (2007) Backyards, Ultimo, NSW: Wollongong University Press, produced by Halstead Press.

Karskens, G. (2006) “The Environmental City - Rapporteur Summary”, in P.Troy (ed.) The state of Australian Cities, State of Australian Cities Conference 2005, http:/www.griffith.edu.au/_data/assets/pdf_file/0012/81102/soac05-refereedproceedings.pdf, last accessed 5 March 2010: 8-13.

Karskens, G. (2009) The colony: a history of early Sydney, Crows Nest, NSW: Allen and Unwin.

Lunney, D. (2001) "Causes of the extinction of native mammals of the Western Division of New South Wales: an ecological interpretation of the nineteenth century historical record", The Rangeland Journal 23: 44-70.

Lunney, D. (2010) 'A history of the debate (1948-2009) on the commercial harvesting of kangaroos, with particular reference to New South Wales and the role of Gordon Grigg', Australian Zoologist 34: 383-430.

Lunney, D. ms a. Examining the changing relationships between wildlife management and society: I. the expanding role of government in conserving the native fauna of NSW. Ms in review.

Lunney, D. ms b. Examining the changing relationships between wildlife management and society: II. a zoological critique of Peter Singer's Animal Liberation and its relevance to conserving the native fauna of NSW. Ms in review.

Lunney, D. ms c. Ethics and Australian mammalogy: reflections on 15 years (19912006) on an animal ethics committee. Ms in review.

Lunney, D. and S. Burgin (eds) (2004) Urban Wildlife: more than meets the eye, Mosman, NSW: Royal Zoological Society of NSW.

Lunney, D., P. Eby, P. Hutchings and S. Burgin (eds) (2007) Pest or Guest. The zoology of overabundance. Royal Zoological Society of NSW, Mosman, NSW.

Lunney, D., Baker, J., Matthews, A., Waples, K., Dickman, C. and Cogger, H. (2007a) Overabundant native vertebrates in New South Wales: characterising populations, gauging perceptions and developing an ethical management framework. in Pest or Guest. The zoology of overabundance, edited by D. Lunney, P. Eby, P. Hutchings and S. Burgin. Royal Zoological Society of New South Wales, Mosman, NSW:158-173. 
Lunney, D., Munn, A. and Meikle, W. (eds) (2008) Too close for Comfort: contentious issues in human-wildlife encounters. Royal Zoological Society of NSW, Mosman, NSW.

Lunney, D., P.Hutchings and D.Hochuli (eds) (2010a) The natural history of Sydney, Mosman, NSW: Royal Zoological Society of NSW. In press

Lunney, D., R.Close, M.S.Crowther, J.Bryant, I.Shannon, K.Madden and S.Ward (2010b) "The koalas of Campbelltown, south-western Sydney: does their natural history foretell of an unnatural future?" in D.Lunney, P.Hutchings and D.Hochuli (eds) The natural history of Sydney, Mosman, NSW: Royal Zoological Society of NSW. In press.

McDonnell, M.J., A.K.Hahs and J.H.Breuste (eds) (2009) Ecology of cities and towns: a comparative approach, Cambridge, UK: Cambridge University Press.

Mumford, L. (1961) The city in history. Its origins, its transformations and its prospects, Ringwood, Victoria: Penguin Books.

Rackham, O. (2006) Woodlands. Harper Collins, New Naturalist Series, UK.

Recher, H.F. (1986) "Maintaining our natural legacy: the ecology of planning", in H.Recher, D.Lunney and I.Dunn (eds) A natural legacy: ecology in Australia, Rushcutters Bay, NSW: Pergamon Press.

Recher, H.F. 2010. A not so natural history: the vertebrate fauna of Sydney. D.Lunney, P.Hutchings and D.Hochuli (eds) The natural history of Sydney, Mosman, NSW: Royal Zoological Society of NSW. In press.

Recher, H.F., D. Lunney and I. Dunn (eds) (1986) A natural legacy: ecology in Australia, Rushcutters Bay, NSW: Pergamon Press.

Robin, L. (2007) How a continent created a nation, Sydney: UNSW Press.

Singer, P. (1975) Animal Liberation. First published by Jonathan Cape, UK, paperback edition published 1983 by Thorsons, Northhamptonshire, UK.

Sjoberg, G. (1965) "The origin and evolution of cities". This paper originally appeared in the September 1965 edition of Scientific American. Reproduced in Cities: their origin, growth and human impact. Scientific American readings, San Francisco, California, USA: W.H.Freeman and Co.

Stilwell, F. (2000) "Ways of seeing: competing perspectives on urban problems and policies", in P.Troy (ed.) Equity, environment, efficiency: ethics and economics in urban Australia, South Carlton, Victoria: Melbourne University Press: 13-37.

Troy, P. (2000) "Introduction: ends and means", in P.Troy (ed.) Equity, environment, efficiency: ethics and economics in urban Australia, South Carlton, Victoria: Melbourne University Press: 1-12.

Winston, D. (1957) Sydney's great experiment. The progress of the Cumberland County Plan, Sydney: Angus \& Robertson. 